\title{
European Union Studies as power/knowledge dispositif: Towards a reflexive turn
}

\author{
Lucie Chamlian (chamlian@ips.uni-kiel.de) \\ Kiel University, Germany
}

In the light of the so-called 'polycrisis' faced by the European Union, this article engages the contemporary 'crisis of European Union Studies' (EUS) by exploring how this field has been historically formed and relationally constituted. Bringing Foucaultian tools to the history and sociology of knowledge, it foregrounds the strategic interplay of power and knowledge and unpacks two distinctive strategies that structure the epistemic field: on the one hand, the European Commission's repeated interventions into the academic field through the Jean Monnet Programme and, on the other, scholarly practices that seek to arrest the identity of the field in the context of methodological and disciplinary competition. It will be argued that the respective valorisations they operate participate in an economy of knowledge that has deferred the engagement with other methodologies and objectivities. The findings presented in this paper eventually encourage a reflexive debate about what EUS stands for and how it possibly needs to be reconstructed.

Keywords: European Studies, Power, Sociology of knowledge, Crisis, Dispositif

\section{Introduction}

Challenging the category of the universal, Michel Foucault has made a critical but oft-neglected contribution to the sociology and philosophy of science which have traditionally concentrated on the formal and natural sciences. Refuting Western humanism's separation of power and knowledge, Foucault's work incisively highlights the critical role played by the "dubious (...) disciplines" ${ }^{1}$ of the social sciences and humanities (SSH) in the transformation of modern power, subjects and government (Foucault, 1989, 197). Strikingly, the analysis of the history and sociology of knowledge has not constituted a prominent endeavour in the similarly "dubious" field of European Union Studies (EUS). Recent contributions have started to address this gap (Rosamond, 2007, 2016; Jensen \& Kristensen, 2013; Klinke, 2015; Adler-Nissen \& Kropp, 2015; McMahon, 2017), but despite an emergent scholarly interest, EUS still lacks a collective reflection on its entangled historical,

\footnotetext{
${ }^{1}$ The term "dubious" is not used here to judge the scientificity of the social and human sciences but to highlight their singular formation and ambivalent standing in the order of knowledge. In his archaeology, Foucault observes that the human sciences (sociology, psychology, history, literature) have emerged in the interstices of three dimensions of knowledge (philosophy, the natural sciences and the empirical sciences - biology, economics and philology). As a consequence thereof, its object of knowledge, Man, constitutes "a positive domain of knowledge" but not "an object of science" (Foucault, 2005, 400, original emphases). This distinction, however, does not aim at discrediting these disciplines. To the contrary, all of Foucault's analyses have shown their tremendous significance in transforming power, subjects and rules under modernity.
} 
social and economic conditions of production. Where the history and sociology of knowledge have been addressed, two genres have typically prevailed: intellectual histories focusing on the 'national' peculiarities of academic 'communities' (e.g., Bindi \& Kjell, 2011) on the one side, and sociologies of knowledge that treat EUS as a transnational quantifiable field but usually display an Anglophone bias, on the other (e.g., Keeler, 2005; Jensen \& Kristensen, 2013). Approaching the field through the transversal struggles, politics and power relations that structure it, in contrast, remains an under-explored topic that this piece taps into via Foucault's infamous conceptualisation of power/knowledge relations.

As textbooks commonly present EUS as a methodologically pluralistic endeavour, this selfunderstanding has been increasingly challenged in the twofold context of the ubiquity of crisis discourses and the dominance of specific ways of knowing (Ryner, 2012; Klinke, 2015; Whitman \& Manners, 2016; Bulmer \& Joseph, 2016). Contributing to this critical literature, the article interrogates the intellectual and institutional shape of EUS, continuing reflections on the marginality and 'belated arrival' of those 'critical approaches' - inter alia, Marxist, Gramscian, postcolonial, poststructuralist and feminist approaches - that have developed over decades in other SSH fields. Instead of stocktaking anew 'theories', 'paradigms' and 'schools' in EUS, it explores the techniques and dispositifs that co-construct the domain of knowledge, its objects and subjects. It will argue that the rarefaction of critical perspectives in EUS is the side effect of the interlinking of (at least) two heterogeneous strategies that steer the scholarly environment: the European Commission's intervention into the field through its sponsorship of European integration studies as well as scholars' own steering through 'debates'. While these do not exhaust the constitution and enclosure of the field, they exemplarily highlight the interplay of power strategies and techniques of knowledge. The exposure of these entanglements, in turn, poses challenging questions to scholars, as it resituates their professional activity within social orders, normative spaces and struggles and recalls the fragile constitution of SSH disciplines. Through its exemplification of how scholarly knowledge-production unfolds in a field of power, this piece counters the depoliticisations that have obscured how order is contingently produced.

The article starts with a brief presentation of the epistemological crisis of Europe before introducing the power/knowledge dispositif as a distinctive possibility to investigate the "history of the present" (Foucault, 1995, 31). This analytical tool decentres the problem of the legitimacy of knowledge, foregrounding instead the strategic configuration of social, material and discursive relations that make specific epistemic endeavours possible. This relationality will then be explored through the European Commission's sponsorship of European integration studies. Special attention will be paid to how epistemic and social relations have been nurtured through the academic Jean Monnet Programme in which the Commission becomes at once the object of knowledge and its sponsor. The article then proceeds to a discussion of how the scholarly debate between rationalism and constructivism has intervened into the order of knowledge and sought to bring the category of European integration studies and European Union Studies under the control of rationalist political science.

\section{The political and epistemological 'crisis' of Europe}

As 'Europe' stumbles from 'crisis' to 'crisis', from financial crisis to political disintegration via the patrolling of humanitarian and social solidarity, critical scholarship has pointed at the limits of 'mainstream' positivist-rationalist science in grasping ongoing transformations of political orders and social power (Ryner, 2012; Smith, 2014; Kreuder-Sonnen, 2016). Since the lawlikeness of social life and the predictability of the future are core tenets of positivist science, the inability of these theories to predict events such as Brexit or the Hydra of 'financial/banking/debt/Greek/Eurozone crisis' have cast a critical light on their self-proclaimed scientific superiority and their claim to best know what 'Europe' is, where 
'politics' is, whose and what knowledge is most 'relevant'. The recent critique of the 'mainstream' suggests that the current 'crises' are not decoupled from academia but entangled with a crisis of knowledge. Critical sociology further hints at a crisis of critique, illustrated by the mainstream's uncritical acceptance of crisis discourses. By treating 'crisis' as an objective fact and external reality, positivist theory contributes to its objectification and simultaneous depoliticisation, as it refrains from seeing it as a political mobilisation (particularly recurrent in the field of foreign policy) and as a political category that needs to be interrogated (but is not, as neoclassical economic theory exemplifies) (Vauchez \& Mégie, 2014).

Further analysis of the scholarly treatment of the 'financial crisis' has made two penetrating observations about Europeanist knowledge-production (Smith, 2014). First, economic knowledge in EUS journals has not been monopolised by economists but by political scientists. Second, the literature evidences an over-representation of neoclassical theory which conceals heterodox approaches that investigate economic and political contingencies. Methodologically, the analyses further concentrate on the whole, that is, the macro-level of analysis, thereby disengaging from and silencing the micro-levels. This politics of publication then produces an intellectual space which reciprocates the claim of the superiority of the orthodoxy: economic determinism epitomises the dominant framework of thought and action. It thereby continues the work of depoliticisation of the 'crises' by evacuating the analysis of political struggles and power relations from the publication circuits praised for their 'impact' and intellectual leadership in EUS. Smith $(2014,42)$, though, suggests that the rarefaction of critical scholarly discourse is less a peculiarity of the Europeanist field than a symptom of the general state of the social sciences.

The intellectual influence of the neoclassical approach has also been observed in mainstream EUS political science. According to Manners \& Whitman $(2016,4)$, the empirical research agenda pursued by the mainstream has foregrounded "institutions, policy-making processes and a normative agenda focusing on institutional efficiency". This agenda has concealed "the neoliberal preferences for market economics" and normalised a bias that occults "the everyday socio-economic concerns of ordinary EU citizens and non-EU citizens" (Manners \& Rosamond, 2018, 35). This taken-for-grantedness of the Single Market has further gone hand in hand with a continuous marginalisation of those approaches that decentre its frames, assumptions and interrogations (Manners, 2003). The fact that the critique of positivism only recently spreads in EUS when it has developed for decades in other networks and SSH fields is remarkable. It lends itself to an interrogation of the particular relations and temporalities that have been performed and made acceptable in the field. As critical scholarship accents the link between epistemology and hegemony and the exclusions it enacts, the precise techniques and strategic arrangements that steer epistemic orders merit a consideration of their own.

\section{Power/knowledge dispositifs: Towards a critical sociology of knowledge}

Critical geographers and political sociologists have recently explored the nature of the link between European integration studies and EU institutions. Klinke $(2015,570)$ suggests that one of the reasons for the late mobilisation of so-called critical approaches is linked to a "policy-academy nexus" which tends to align research questions, problems and concepts with the frames, concerns and objectives of EU policy-makers. Critically dissecting the geopolitical dimension of the EU's Jean Monnet Programme, he observes two similarities between EUS and older area studies like Sovietology: first, a dependence on governmental funding and, second, a twin definition of the object of knowledge as "a geographical area and a particular polity" (Klinke, 2015, 581). Other research has similarly pointed at EUS as an 'academico-political' enterprise but as one conditioned by the porosity of the boundary of the political and academic fields rather than by ideology and domination (Vauchez \& 
Robert, 2010; Vauchez \& Mudge, 2012). Lacking solid grounding in national disciplines, EUS has emerged in a transnational field in which professional mobility across European institutions, universities and think tanks is the norm rather than the exception. An "exceptional acquaintance with each other's modus operandi" has exemplarily been observed in the field of European security (Kurowska \& Kratochwil, 2012, 102). These critical insights have received little attention in the EUS literature, raising questions about the status of critique, the limited mobility of knowledge and the selective reception of pieces. It may not be wrong to suggest that the neglect of these reflections is partly linked to a positivist discourse of science and the divisions it operates (value/fact, truth/power, subject/object), which decouple knowledge-production from its historical, political and cultural contexts. Through this lens, scholarly introspection then can only take the form of assessments of theories and methods on the basis of positivist criteria.

Similarly, the 'traditional' sociology of knowledge accounts for the development of disciplines, drawing on a dualistic operation that separates 'internal' from 'external' determinants in order to establish 'causal' relations (Wæver, 1998; Bell, 2009). This inside/outside divide implies that disciplines are 'pure' spaces rather than social ones, either defined by autonomous and internal norms or, to the contrary, by 'external' events. Recent research has started to challenge these dualistic divisions by highlighting, for instance, the transnational roots of intellectual movements. These analyses contest the self-containment of disciplines within 'the nation' on the one hand, and the independence of disciplines from politics and societal power structures, on the other (Heilbron et al., 2008; Boncourt, 2015; Pfister, 2015; Boncourt \& Calligaro, 2017). Like earlier Marxist contributions, this sociology acknowledges the social situatedness of knowledge but it does not treat knowledge as structurally determined by the ruling class.

Foucault's work, in turn, offers new opportunities for analysing the conditions of possibility of fields of knowledge. His thorough historicisation of objects of knowledge, the subjects to be governed and the dividing practices that organise social life grants no privilege to universal categories of thought. Although he invited others to experiment with his original tools, the power/knowledge dispositif has been little employed in the history and sociology of knowledge. Peltonen $(2014,218)$ compellingly notes that "those social sciences designed to avoid historical specificity and create the illusion of a universality of concepts and methods" have "largely ignored" this analytical instrument while, reversely, finding Foucault's "discourse analysis" more acceptable. The emergence of social scientific objects of knowledge, though, has a history which is at once more precise, mundane and violent than the institutional or philosophical discourses that naturalise and legitimise them.

"Perhaps [...] we must abandon a whole tradition that lets us imagine that there can only be knowledge where power relations are suspended and that knowledge can only develop outside of its injunctions, its demands, and its interests. [...] We must admit rather that power produces knowledge [...]; that power and knowledge directly imply or implicate one another; that there is no power relation without the correlative institution of a field of knowledge, nor is there knowledge that does not presuppose and constitute at the same time power relations. These [are] 'power-knowledge' relations" (Foucault, 1995, 27).

Foucault here advances that knowledge and power are not antagonistic but presuppose each other. This means that objects of knowledge are neither anterior nor exterior to the power relations and discourses that make it possible to speak about them. In plain terms, "between techniques of knowledge and strategies of power there is no exteriority" (Foucault, 1978, 98). The crux of Foucault's proposition is that power and knowledge are indissociable but yet not reducible to each other. Despite their constant interaction and articulation, they remain distinctive. Their precise relation and the form of reciprocation, in 
turn, historically vary. Further, Foucault argues that in order to govern, power needs to know what to govern. What can be known, in turn, is shaped by the "processes and struggles that traverse it" (Foucault, 1995, 28). Hence, objects of knowledge are not the mirror of a transcendental principle and reality but dynamic constructions subject to transformations as knowledge and power strategies rearticulate themselves and shift. It is this idea that power and knowledge form a strategic link that will be scrutinised in the empirical parts.

Power/knowledge relations further develop in a strategic field which is captured by the term "dispositif". A dispositif responds "to an urgent need" raised "at a given historical moment" (Foucault 1980, 195, original emphases). It consists of "a thoroughly heterogeneous ensemble (...) of discourses, institutions, architectural forms, regulatory decisions, laws, administrative measures, scientific statements, philosophical, moral and philanthropic propositions" (Foucault, 1980, 194). As it encompasses a multiplicity of social, material and discursive elements whose connections constantly evolve, the analysis of a dispositif is always partial. The dispositif, however, should not be confused with a descriptive or ideal-typical concept. It neither denotes an ontological category nor a homogeneous or coherent unity. It is an analytical tool in that it stakes out "the nature of the connection that can exist between these heterogeneous elements" (Foucault, 1980, 194). It is a strategic configuration directed at the government of men and built on a moving ground of relations. Ultimately, this prism of analysis carves out a distinctive possibility to write the history of the present without falling prey to the universal and teleological histories of European integration.

\section{The construction of the 'European' academic: A transversal struggle to create a Euro- pean civil society alongside the unified market}

Engaging the historical dispositif of European integration, this part identifies how political institutions such as the European Commission have supported the creation of European integration studies, as part of a strategy that aims at constructing a unified 'European' civil society. It particularly scrutinises the premises and workings of the Jean Monnet Programme, how it nurtures power relations and which methodological valorisations have resulted from the Commission's interventions.

\subsection{Involving academia through the University Information Policy}

Although the European Community had no official policy and no legal mandate to act in the field of higher education, relations with academia have been established and shaped through the Communities' Press and Information Service since the early 1950s. As hosted by the European Coal and Steel Community's (ECSC), the Press and Information was divided in two units: one branch provided the trade union sector and the European Assembly with technical and economic information on European integration and the other one furnished political communication and information to the wider public (Rye, 2009). It was then assumed that information activities would contribute to educate 'European' citizens and assist the formation of a 'European' public opinion, along the same lines as 'national' public opinion. As Harrison \& Pukallus $(2015,234)$ put it, the Information Service aimed at „facilitating a European civil consciousness that would provide the basis of European citizen's rights and a sui generis European identity". When the different Information Services of the Communities merged into the "Joint Press and Information Service“ in 1958, a special unit for "Youth and University Information" was set up. Identifying the university as a political stake was consonant with the view that had led to the creation of vocational institutions such as the College of Europe. Notably, the Brussels Treaty of 1948 whose primary purpose was to establish collective defence also aimed at the promotion of "economic, social and cultural collaboration". Seen as "tools of diplomacy", higher education 
and culture were deemed to have "a 'cultural propaganda' mission" (Corbett, 2005, 37). As Jacques-René Rabier, Head of the Press and Information Service, himself put it, scholars would provide "a sort of legitimacy of a great significance by making [European integration] the object of research, teaching and examination" (Rabier, 1965, 20). While universities had been instrumental in forming the national unity and national elites, it was believed that they could play a "similar role in the formation of the European unity" (Calligaro, 2013, 21). The nurturing of special relations with young researchers and scholars interested in European integration was thus part of a political strategy that aimed at creating 'European' citizens supportive of European unification. For Calligaro $(2013,21)$, this marks the Commission's "militant approach to information".

Already in 1953, Rabier had offered French historian, Pierre Gerbet, a contract to write about the origins of the Schuman Plan. In 1959, a Community prize for theses on European integration was launched. A Centrale de Thèses collecting and circulating doctoral theses to relevant Commission services was also established and in 1961, the "Institut de la Communauté Européenne pour les Études Universitaires" was tasked with the production of a regular bulletin on "University Research and Studies on European integration" (EC, 2014, 12-14; Lastenouse, 2011, 7). From 1963 on, the Commission started to provide small research grants to students of European integration. In the same year, European Documentation Centres (EDCs) were launched in several member states as well as in East European countries and in China. These allowed students and scholars to access original publications from the European institutions as the former were held to be "one of the major groups of EC information users" (Calligaro, 2013, 22). In addition, the centres were to be managed by researchers and professors themselves rather than by the university administration. This enabled the Press and Information Service to establish direct contacts with academics through informal structures $(E C, 2014,18)$. While the university has been historically central in the creation of national imaginaries, it has also watched over its independence from political interference. Consequently, the establishment of and the provisions tied to the EDCs were tactically adroit as they circumnavigated potential resistance from national administrations. Surprisingly and despite the Communities' critique of nationalism, the role of universities in the consolidation of nation-states was not deemed "a problem to avoid" but, to the contrary, "an example to be followed" (Calligaro, 2013, 45).

In 1962, the Press and Information Service commissioned the first Community-wide opinion poll (Aldrin, 2010, 86). This survey concluded that a large majority of the public was supportive of European unification, yet lacking passion for the political project. It further highlighted considerable variation between groups, for instance, "men were better informed than women, industrialists were better informed than workers, and educated people were better informed than the uneducated" (Rye, 2009, 154). As the repartition of the Community budget in the subsequent years indicates, the Communities did not close this gap but continued to target opinion leaders more strongly than mass opinion. In other words, priority was given to "a group of already convinced Europeans" as it was believed that these groups would exert the strongest influence on the dissemination of information and the shaping a favourable public opinion (Rye, 2009, 154-155). It is worth to note that when Jacques-René Rabier left the European Commission and became a Special Adviser in 1973, he launched the Eurobarometer project as a technique for optimising the Communities' information policies through the production of a pan-European reality and the measurement of public attitudes. Empowering quantitative empirical social science, this new instrument has served to construct the European public opinion by demonstrating its existence and making it both statistically visible and governable (Aldrin, 2010). From a political science perspective, it is also interesting to highlight that the paternity of the term "Eurosphere" has been precisely attributed to Rabier (Meynaud \& Sidjanski, 1965). 
Since 1962, the Commission has further involved scholars in reflections about the professionalization of the Europeanist academe, supporting the launch of associations to promote European integration studies and thereby facilitating the construction of scholarly networks. The French Commission for the Study of the European Communities was born out of these in 1965, followed by the British University Association for Contemporary European Studies and the German Arbeitskreis für Europäische Integration in 1969. As national associations kept mushrooming throughout the $1970 \mathrm{~s}$ and $1980 \mathrm{~s}$, they were brought under the umbrella of the European Community Studies Association (ECSA) in 1987, sponsored by the Commission. All these small actions point towards how a multiplicity of microevents has fostered both the monitoring of the academic investment and the establishment of relations between an emergent Europeanist scholarship and the Community institutions. By targeting the academic subject as a relay of European integration and encouraging the development of collaborative relations, Community services have facilitated the production of new relations, while intervening in a transversal struggle to create a unified European public.

\subsection{Rewarding Europeanists through the Jean Monnet Action}

Universities, though, were not evenly instituting teaching and research on European integration. Throughout the 1980s, the DG Press \& Information (DG X) intensified its actions towards the university milieu. This continuous effort notably coincided with the rise of the democratic deficit critique, the problematisation of the still unrealised European polity and subsequent attempts to 'fill this gap' through the launch, for instance, of the Erasmus project designed to facilitate students' mobility. The University Information unit proposed a new instrument to consolidate relations between academics and the politico-administrative spheres and to stabilise the existing informal networks. The creation of a grand-scale university chairs project became the means for pursuing this consolidation and for valorising European integration studies as this specialism remained widely hidden behind the labels of 'traditional' disciplines (HAEU, EN-2053). The DG sought the support of ECSA professors who acquiesced to the idea and became involved in the preparatory work for the Jean Monnet Action (JMA). Indeed, ECSA's role was not solely to coordinate academic associations in the field but to provide support to the project and to legitimate the Commission's action in this sensitive field. DG X's ability to show that there was a demand and support by professional themselves would facilitate its negotiations for the provision of Community funds. The "Liaison Committee of National Conferences of Rectors and Presidents of Universities" was further tasked to explore the feasibility of the project and, by the same token, to secure its acceptance by the universities (EC, 2011, 278). The "Confederation of University Rectors" had already proven to be a precious ally for the launch of the Erasmus project (HAEU, EN-2079). In 1989, a Commission-sponsored conference on "The Place of European Integration in University Programmes" discussed the possibilities and design of the JMA. In addition, the "University Council for the Jean Monnet Action" was set up. This informal advisory group was conceived as an "immediate relay" between the Commission and the universities (HAEU, EN-2053). It was composed of four representatives from ECSA, four members from the Liaison Committee and presided by the President of the European University Institute (EUI).

Initially, the University Information unit projected the creation of "teaching and research units on the construction of Europe in each university of the Community" (HAEU, CRE-365). For the promoters of JMA, the implementation of European Chairs would continue the educational purpose and help „to form European citizens endowed with a strong European consciousness" (Calligaro, 2013, 31). Eurobarometer statistics served to legitimate the endeavour and to argue that young people aged 15-25 were favourable to European unification when they had knowledge about Community affairs. As the Treaty of Maastricht which 
would institute European citizenship was being negotiated, the opportunity was given to assert the need for knowledgeable students and to coin that students' demand for European integration curricula was on the rise. Interestingly, the University Information unit was not solely concerned about the decline of doctoral theses on European integration but also about the marginality of political science in Europe and the predominance of American theorisation on European integration (HAEU, EN-2054). Established in 1989, the Jean Monnet Action focused on the social sciences as these were seen to develop a 'European dimension'. The selected disciplines were notably the same as those instituted at the EUI: law, economics, political science and history. In order to secure Community funding, the JMA was first presented as a 'pilot' action instituting 'European chairs'. Evaluated as a success, the JMA was constantly renewed throughout the 1990s with the steady support of the European Parliament. Modules and courses were additionally introduced in 1995, followed by centres of excellence in 1997.

Calligaro $(2013,17)$ underlines that the Commission has managed to provide incentives to work on European integration at universities in a way that would disarm the critique that it would spread "a gross form of propaganda". Indeed, through the involvement of the University Council, the JMA could be presented as an action designed for the academic world and run by academics themselves. In the period 1989-1999, Jean Monnet projects were assessed by the University Council. The latter ensured the projects' follow-up and advised the Commission in setting priority areas of action. It was also in charge of evaluating the Action in 1993, 1995 and 1998. The background and individual trajectories of the members of the University Council are worth to point out. First, prior to his appointment as President of the EUI (and of the University Council), Emile Noël had been serving the European Commission for twenty years (1967-1987). This position enabled Noël to act at once towards the university milieu and towards the Commission for brokering support for the JMA (Calligaro, 2013, 33). Second, some members of the University Council became Jean Monnet professors while serving on the University Council. As the members of University Council were renewed, nearly all of them had been recipients of the JMA before acting on the University Council. Third, since 1997, the Presidency of the University Council was no longer held by the President of the EUI but by members of the European Parliament $^{2}$. The representation of the European Parliament on the University Council could be seen as the valorisation of an institution which provided crucial support to the continuity of the JMA. As Helen Wallace observes, the JMA has brought "friends of the project" together (EC, 2011, 245). These backgrounds add some nuances to the 'independence' of the University Council, not least given that some of the advisers became beneficiaries of the programme. Closing the circle, with the exception of the first one, all ECSA Presidents were also Jean Monnet professors.

This special "umbrilical cord relationship" that connected the University Council and ECSA to the Commission did not last, though (EC, 2011, 274). In the 1990s, the continuity of the JMA remained fragile due to its delicate legal status, which made the Action dependent on its political promoters. The transferral of the JMA from DG $X$ to DG Education \& Culture in 2001 was not insignificant: it contributed to the stabilisation of the JMA budget, as the Action became a Community programme in 2004 (and subsequently integrated in the "Lifelong Learning Programme" in 2007 and in the "Erasmust" Programme in 2014). This administrative transfer also led to the dissolution of the University Information unit. The corruption scandal that had brought the Santer Commission down in 1999 and the following reforms carried out to enhance the transparency of the Commission also affected the

\footnotetext{
2 These were Leo Tindemans and José María Gil-Robles who respectively served on the University Council from 1997 to 2001 and from 2001 to 2017 - year in which the University Council was removed from the Expert Group Register of the European Commission.
} 
JMA. By 2001, the University Council was no longer the exclusive advisor of the Commission which meanwhile drew on a larger "pool of experts" (EC, 2004, 40). The Jean Monnet Programme was also submitted to external evaluation. The transformation of the links between the European Commission and the University Council was also furthered by the setting up of the "Educational, Audiovisual and Culture Executive Agency" (EACEA) in 2006. This Agency was in charge of implementing the Lifelong Learning Programme (LLP) whereas the definition of "objectives, strategies and priority areas of action" remained the prerogative of DG Education (EC, 2013, 11). If the University Council had played a "navigational and arbitrational role" throughout the 1990s, its role diminished in the 2000s. As DG Education expanded its control over the Jean Monnet Programme through the LLP, the selection of projects became more political (EC, 2014, 40). While the University Council also used to define the conference topics of the ECSA/Jean Monnet Conferences, these were now determined by the Commission (later joined by the European External Action Service), unsurprisingly foregrounding policy themes of primary interest to the Institutions (EC, 2014, 26). The EACEA further holds that it has assisted the Commission "in building up a higher political impact of the JMA through various channels" (EACEA, 2016b, 27). Retrospectively, Jacqueline Lastenouse, who had developed the JMA, regrets that the University Council was not institutionalised and endowed with the prerogative to conduct the JMA on behalf of the Commission (Lastenouse, 2011, 18).

Since its inception, the University Council had actively promoted the consolidation and expansion of Jean Monnet activities. In this period, the official criteria guiding the assessments were fourfold: first, a focus on European integration; second, the proposal ought to represent a new initiative in the applicant's university and, third, target the first and second cycles of studies; and fourth, evidence academic quality (HAEU, EN-2004). While the Commission aimed at achieving a geographical and disciplinary balance, it also prioritised actions towards single fields. Teaching of Community law was, for instance, deemed too marginal and thus deserving special attention (HAEU, EN-2053). Selection criteria started to change in 2001, leading to a devaluation of the required 'newness' of the initiative, stressing instead "scientific quality and excellence" (OJ, 2001, 23). Under LLP and Erasmus+, the criteria were further redefined, with the notable introduction of the criterion of "impact and dissemination". The JMA was, indeed, from the outset legitimated through a 'politics of numbers'. The early success of the Action was measured in terms of the discrepancy between the high number of expressions of interest and the limited number of grants. Current strategic targets of the Commission are twofold: increasing the number of nation-states targeted by the Jean Monnet Programme as well as the number of students and of the 'wider public' reached by the Jean Monnet activities. Governed by numbers, the promotion of scholarly "excellence" is meanwhile also linked to the EU's foreign policy goals. Initially responding to the need for the creation of 'European' citizens and the objectification of the 'European dimension' through university teaching and research, the JMA has been remoulded into a dispositif that promotes "European (Union) Studies" and the EU's image abroad, effectively becoming an instrument of "public diplomacy" (Yang, 2015).

\section{5. 'Mainstreams' and epistemological competition}

If power was omnipotent, there would be no need for inventing techniques and refining dispositifs of government (Foucault, 1980). The previous section has illustrated the different techniques through which the European Commission has intervened into the university milieu by sponsoring teaching, research and professional associations on European integration. Empowering the academic minority of 'Europeanists', it has produced new relations of intellectual collaboration, incentivised by funds and recognition. Using academics as multiplicators of European integration, the JMA has not solely aimed at educating 
citizens and building the European civil society that was missing in the economic construction of Europe. It has also linked the Jean Monnet professors to its political prisms and working methods (policy and problem-solving), making this kind of association not only acceptable but 'prestigious' (EC, 2014, 28). While the JMA has made an important contribution to the mainstreaming of the category of 'European integration studies', political scientists in particular have pursued the 'scientific normalisation' of the study of the EU in its struggle for authority, recognition and funds. This section discusses how the diffusion and rationalisation of 'European integration studies' and 'EUS' as social sciences have (dis)incentivised the collaboration with the wider $\mathrm{SSH}$.

\subsection{The Commission's interventions into the economy of knowledge}

While the Jean Monnet Programme does not prescribe the contents of teaching and research activities, it nurtures the order of knowledge by arranging the relations between disciplines.

To start with, the Jean Monnet Programme has disentangled the 'social sciences' from the 'humanities'. Sociology, philosophy, geography and arts, for instance, are not actively targeted by the Programme. Yet, they may benefit from funding "when they include an element of teaching, research or reflection on the EU and contribute, in general, to the Europeanization of the curricula" ${ }^{3}$. Given the Commission's early interest in building a European civil society, the neglect of sociology as the study of society is remarkable. As the quote above evidences, sociology is not deemed to be genuinely 'Europeanist' and sociologists themselves have observed the predominance of a "methodological nationalism" in their field (Guiraudon \& Favell, 2007, 3). In this respect, it is interesting to note that the pan-European public opinion surveys pioneered by the Press and Information Service and refined through the Eurobarometer instrument were themselves producing a specific kind of 'sociological' knowledge (on collaborations between social scientists and the Commission, see Aldrin, 2010).

Alongside the divide enshrined by the Commission's definition of 'Europeanist' disciplines, the support granted to the individual disciplines covered by the Jean Monnet Programme in the period 1990-2018 displays significant asymmetries (EACEA, 2019). The notorious under-representation of History has already been addressed. Calligaro's analysis details the struggles that took place during the 1970s and 1980s between the European Commission and historians of 'European integration history'. It shows how the Commission actively intervened into historical methods by promoting a teleological and elitist approach to History. Most importantly, it recounts the Commission's successive attempts to establish the EUI's History Department and the "Liaison Group for Contemporary Historians" as its privileged academic interlocutors (Calligaro, 2013, 39-74). As both had failed, the Jean Monnet network became the new space for cultivating a privileged partnership. It is not accidental that the Commission presents the Jean Monnet community as its own "think tank" (EC, $2014,4)$ and refers to Jean Monnet professors as "ambassadors [of European integration] in the Member states, in the candidate countries, and around the world" (EC, 2011, 18). Indeed, some of these professors had been involved in the elaboration of EU concepts and policies such as European "governance" or "Constitution" (Vauchez \& Robert, 2010). As recent clusters meeting of Jean Monnet professors show, the link between academia and political mobilisation is not deemed problematic. To the contrary, recent reflections have focused on "how European Studies could better support the EU Commission" and help "to shape favourably the public debate about the EU" (EACEA, 2016a, 3-8). 
As the Jean Monnet budget was consolidated in 2007, the 'traditional' disciplines and interdisciplinary studies were complemented by new subfields and subject areas. This extension encompassed knowledge fields that are foremost relevant to foreign policy: "International Relations and Public Diplomacy", "Comparative Regionalism", "Intercultural studies" and "Communication and Information Studies". In numerical terms, interdisciplinary studies have become the most targeted field since 2008. Since then, the number of grants attributed to this field has oscillated between a third of the total number of grants per year and more than a half thereof $(55 \% \text { in } 2013)^{4}$. Among the disciplines, legal studies have prevailed in the period 2008-2018. Political science ranks second if one regroups the Commission's categories 'political and administrative studies', 'International Relations and Public Diplomacy' and 'Comparative Regionalism'. Support to economic studies, in contrast, has continuously decreased since 2008 , regularly falling below the $10 \%$ bar and only exceptionally accounting for $12,4 \%$ of the grants in the year 2012 . While the marginality of economic contributions in EUS outlets has been noted (Smith, 2014), the Jean Monnet data also evidences a decreased sponsorship of economic studies by the European Commission.

If actions in the field of law, history, economy and political science aim at mainstreaming the 'European dimension' in each of these disciplines, interdisciplinarity represents the 'mainstream' in numerical terms. By valorizing specific disciplines and certain methodologies, the JMA sustains at once the establishment of 'Europeanist' streams within 'established' disciplines as well as their collaboration and productive entanglement. It thus simultaneously nurtures the disciplines and counters their closure. Finally, the JMA illustrates disparate and heterogeneous effects on power relations: it has simultaneously empowered margins and minorities (most clearly through the category of 'European integration studies' but also through the promotion of the 'interdisciplinary' methodology), amplified existing asymmetries (see Popa, 2007, in terms of internationalisation) and also created new ones (by establishing the 'prestige' of the Jean Monnet Community over the rest of academia).

\subsection{Scholarly steering in the competition of knowledge}

Prior to the 1990s, the categories of "European Union Studies" and "European integration studies" were almost inexistent. Some argue that their creation is linked to the "mainstreaming of the EU" and to a growing professionalization of academia (Manners \& Rosamond, 2018). Others detail how these categories were mobilised to oppose two objects of knowledge (European integration process vs. political system) and two methodological approaches ('IR grand theorising' and 'comparative political science mid-range theorising') (Rosamond, 2007). Notably, the production and diffusion of these labels coincides with the institution of the Jean Monnet chairs which initially promoted 'European integration studies' in European universities and, later, 'European Union Studies' in the world. Just as this domain was becoming an academic "boom field" (Keeler, 2005), the patrolling of epistemological boundaries has also intensified. As observed in the literature, "the mid to late 1990s saw the possibility of an opening to genuine pluralism, including constructivist and post-structuralist scholarship" but "this door was swiftly closed up" (Manners \& Whitman, $2016,7)$. The stakes were eminently high, as the modern order of knowledge and the project of positivist science were radically challenged across the SSH and relayed by a minority of scholars in European integration studies (Diez, 1999).

Researchers familiar with IR will easily note that the so-called "Third Debate" proclaimed in the late 1980s was never paralleled in EUS (Lapid, 1989). This is not to suggest that disciplines undergo isomorphic transformations but since some scholars were 'double-

\footnotetext{
${ }^{4}$ This data was derived from the Jean Monnet Directory (EACEA, 2019).
} 
hatted', simultaneously publishing in 'IR' and 'EUS' outlets, the small degree of cross-fertilization at first surprises. It is less surprising though, if one considers that the critique of 'post-positivist' approaches primarily targeted the dominance of (Neo)Realism in IR - a dominance that has never been matched in EUS as European integration theories represent variants of liberal, positivist and rationalist science (Hussey, 2010). Europeanist scholarship, in turn, has participated in the 'rationalist-constructivist' debate. The way in which it has been conducted in EUS illustrates the mobility of the argumentations and references that were initially used by IR 'rationalists' against their 'reflectivist' contenders. In IR, social constructivism had precisely emerged as a bridge between the incommensurable poles epitomised by 'reflectivism' and 'rationalism'. By positioning social constructivism as a "via media", its proponents had made ontological dissent about the status of 'ideas' and 'culture' possible but rejected the possibility of epistemological dissent (Wendt, 1992). The anterior division between rationalists and reflectivists had been meanwhile reworked into an opposition between "Science" and "Dissent". The participation of EUS in this debate has played its part in legitimating the peculiar social constructivist position. Spatial metaphors used in IR were relayed in EUS, positioning social constructivism as a "mediator between incommensurable points" (Christiansen et al., 1999, 538-536). Yet, the intellectual topology, premises and cleavages in EUS, as noted above, significantly differed from IR. As one commentator pertinently observes:

"Thanks in part to extensive prior debate in IR, constructivism arrived in EU studies without heavy meta-theoretical baggage. Constructivists mostly attacked the substantive explanatory limits of rationalism rather than its positivist epistemological foundations. Methodological debates were rare and focused on how to show empirically that, and in which way, ideas and discourse matter on European integration. Constructivism in EU studies is not tied to critical or post-positivist meta-theory or interpretative methods" (Schimmelfennig, 2012, 35).

What "constructivism in EU studies" was, was briefly but fiercely debated. From 1999 onwards and in the pages of so-called 'top' journals, proponents of positivist and rationalist political science have drawn clear boundaries between selected interlocutors from the (social) constructivist side whose propositions were worth discussing and the more radical ones with whom debate would be pointless (Moravcsik, 1999b, 670). Post-positivist critics who challenged the superiority of the norms of positivist science were branded as illegitimate interlocutors and as "European activists". In contradistinction to them, "most leading constructivists" would agree that empirical research must submit to the 'scientific method' of empirical falsification (Moravcsik, 1999b, 670, emphasis added). The 'scientific' study of Europe was to be the exclusive playground for hypothesis-testing considered as "the ultimate, and [...] the only standard of what constitutes 'good work'" (Pollack, 2000, 17). "Social theory", as dubbed by its opponents, would not belong to "social science" (Moravcsik, 1999a). Indeed, political scientists' cherry-picking in the philosophy of science and the foregrounding of the figures of Lakatos, Popper and Kuhn was not to be debated (Jackson, 2011). Critique raised at the philosophical and empirical level (Diez, 1999) was considered as a mere diversion from the social scientist's 'true job' which would consist in the accumulation of knowledge through empirical tests (Checkel, 2006, 59).

Indeed, while rationalist proponents have argued that the constructivist vs. rationalist debate was benign for EUS and proof of its scientific maturation (Risse, 2009, 144), lesser emphasis has been placed on the fact that it also resulted in the consolidation of the social position of political science in the competition with adjacent disciplines. The rationalism vs. constructivism debate was largely conducted by political scientists. As social constructivism had become an acceptable competitor and part of the mainstream, 'Europeanist' 
political science could then more easily claim that 'sociological' accounts were part of the methodological canon of EU/European integration research.

As the constructivist vs. rationalist debate unfolded, a new journal was launched. It consecrated both the turn to 'European Union Studies' and the techniques of comparative political science. For the journal's editors, the time was rife for outpacing "the past dispersion of European Union research" as their present showed "a cross-disciplinary convergence towards a unifying approach". Political scientists, regardless of their specialism, were identified as "traditionally [...] the most active groups in European Union studies" (Schneider et al., 2000, 6). The launch of the outlet was supported by the European Consortium of Political Research (ECPR). Promoting the 'unification' of knowledge and the superiority of positivist rationalist methods and assumptions, comparative political science has advanced an apolitical empiricism that neglects that its methodologies are dependent on 'data' produced or commissioned by political institutions, administrations or commercial actors (Adler-Nissen \& Kropp, 2015, 162; Aldrin, 2010). While the literature has critically observed that the rise of comparative political science has displaced the study of 'European integration', one can add more sharply that the scientific project of the unification of knowledge has been pursued by taking the political unification of EU member states for granted.

Scholars have been tempted to argue that Europeanist research was structured by a transatlantic divide with 'Europeans' inclined to 'constructivist' and qualitative techniques and 'Americans' to 'rationalist' and 'quantitative' methods (Verdun, 2003; Moravcsik, 1999b). Jensen \& Kristensen's analysis (2013) has provided more nuanced results, confirming a quantitative preponderance of comparative political science in the field but also an epistemological fragmentation within Europe. Interestingly, the authors identify the EUI and Mannheim University as major producers of rationalist comparative political science. These institutions are particularly striking for their historical ties to EU institutions: the EUI by its legal design and funding structure and Mannheim as a producer of Eurobarometer surveys.

The constructivist vs. rationalist debate has valorised political science as a knowledge-producer. By speaking knowledge to itself and to its subfields rather than engaging the existing plurality of techniques of knowledge, it has severed a twofold exclusion: within political science and towards other SSH fields. The competition in defining what Europe is and how to teach it was further fuelled by a project sponsored by the European Commission, entitled "Enhancing Political Science Teaching Quality and Mobility in Europe". Conducted by the European Political Science Network (2001-2003), it discussed the possibility and desirability of developing a 'core curriculum', featuring political science as the major contributing discipline (Bache, 2006). EpsNet, indeed, competed with the ECPR, seen as an organ of American and Northern European political scientists and aimed to better integrate Southern and Eastern Europe. Due to lack of membership, the network was ultimately integrated into ECPR in 2007 (Boncourt, 2016). The conduct of the rationalist vs. constructivist debate has aimed to re-structure the field and to steer the conduct of academics. It has thereby missed an opportunity to constructively engage other forms and techniques of knowledge, asserting instead the superiority of its methodological specialism and choice over the rest of the field.

\section{Synopsis}

This piece has illustrated how the European Commission's technique of sponsorship and the scholarly technique of debates intervene into unsettled orders of knowledge. It has showed how the promotion of 'European integration studies' has served the political purpose of constructing a 'European' polity and educating 'European' citizens. Through multiple actions, the Commission has co-constructed European integration as an object of research, turning an evolving political construction into an ontological positivity and 
'Europeanist' academics into relays of the political project. Two sets of relations have been particularly nurtured through the Jean Monnet Action and Programme: first, it has produced a normative field in which the collaboration between the funder and object of research, on the one side, and scholars, on the other is not only acceptable but comprised in the definition of leadership and scientific excellence. Second, it has enshrined disciplinary hierarchies by separating selected 'social sciences' from the wider SSH and providing uneven support to the targeted disciplines and fields of study. Just as the category of 'European integration studies' was promoted by the European Commission throughout the 1990s, assisting its multiple institutionalisations, disciplining interventions by political scientists intensified. These took the form of 'debates', consolidating political science as a whole and a specific genre thereof in particular. These have given rise to two types of 'distinguished communities': the interdisciplinary Jean Monnet community on the one hand and the 'positivist' political scientists on the other. While both processes appear to be antagonistic, they converge in the economy of knowledge by marginalising alternative objectivities and critical discourses. The consolidation of positivist-rationalist political science was, in fact, far from being as intellectually innovative and revolutionary as comparativists had it, as the development and mainstreaming of this kind of empirical science started long before with the Communities' militant information policies. The findings therefore provide historical and empirical ammunition to Chris Shore's suggestion (2000, 29), according to which "it would not be unreasonable to assume that 'European Union Studies' are not as critical of the EU as might otherwise be the case". As Europeanist political science has obscured and narrowed what is 'political', the 'critical turn' may be a welcomed opportunity to lay bare the relations through which this field has been constructed.

\section{Conclusion}

This article has highlighted historical and social specificities in the continuous formation of European integration and European Union studies. It has introduced Foucault's power/knowledge dispositif as a tool of analysis which, as was argued, makes a substantive contribution to the history and sociology of knowledge by undoing the internal/external dualism and the truth/ideology binary. Focusing on the strategic arrangement of discursive and material relations, the article has illustrated the operations of a power/knowledge nexus in which scholarly and bureaucratic practice reciprocate each other in the construction of scholarly mainstreams and the marginalisation of specific forms of knowing. The analysis has shown how a new political actor developed specific instruments for intervening into the scholarly field by sustaining networks and infrastructures, promoting an object of knowledge and a Europeanist citizenry. It has further shown how scholars themselves steer the epistemic enterprise through scholarly debates, mimicking disciplining techniques and selective science discourses deployed in adjacent SSH disciplines. As the European Commission is only one among many sponsors in the 'Europeanist' field, further research is needed on the relations that condition the continuous production of the scholarly field and the resistances these trigger. Ultimately, there is no easy answer to the question of how to recast the relation between scholars and those political sponsors who are also the object of research. Yet, by showing the interpenetration of two heterogeneous strategies in evolving dispositifs of goverment, this paper is not an endpoint but hopefully the beginning of a reflexive discussion on the collective positionalities of the field. 


\section{References}

Adler-Nissen, R. \& Kropp, K. (2015). A sociology of knowledge of European integration. The social sciences in the making of Europe. Journal of European Integration, 37(2), 155-173.

Aldrin, Philippe (2010). L'invention de l'opinion publique européenne. Genèse intellectuelle et politique de l'Eurobaromètre (1950-1973). Politix, 1(89), 79-101.

Bache, I. (2006). The Europeanization of higher education: markets, politics or learning? Journal of Common Market Studies, 44(2), 231-248.

Bell, D. (2009). Writing the world: disciplinary history and beyond. International Affairs, 85(1), 3-22.

Bindi, F. \& Kjell, A. (2011). Analyzing European Union politics. Bologna: II Mulino.

Boncourt, T. (2015). The transnational circulation of scientific ideas. Importing behaviouralism in European political science (1950-1970). Journal of the History of the Behavioral Sciences, 51(2), 195-215.

Boncourt, T. \& Calligaro, O. (2017). Legitimising Europe with the social sciences and humanities? The European University Institute and the European integration project (19761986). Serendipities, 2(1), 69-89.

Bulmer, S. \& Joseph, J. (2016). European integration in crisis? Of supranational integration, hegemonic projects and domestic politics. European Journal of International Relations, 22(4), 725-748.

Calligaro, O. (2013). Negotiating Europe: EU Promotion and Europeanness since the 1950s. New York: Palgrave Macmillan.

Checkel, J. (2006). Constructivism and EU politics. In K. Jørgensen, M. Pollack \& B. Rosamond (Eds.), Handbook of European Union Politics (57-76). London: Sage.

Christiansen, T., Jørgensen, K. \& Wiener, A. (1999). The social construction of Europe. Journal of European Public Policy, 6(4), 528-544.

Corbett, A. (2005). Universities and the Europe of knowledge. Ideas, institutions and policy entrepreneurship in European Union higher education policy, 1955-2005. Basingstoke: Palgrave Macmillan.

Diez, T. (1999). Riding the AM-track through Europe; or, the pitfalls of a rationalist journey through European integration. Millennium-Journal of International Studies, 28(2), 355369.

Education, Audiovisual and Culture Executive Agency (2019): Jean Monnet Directory (retrieved 16.05.19).

Education, Audiovisual and Culture Executive Agency (2016a). Good Practices in the context of "A union of shared values - The role of education \& civil society". Jean Monnet Cluster Meeting, Brussels. 
Education, Audiovisual and Culture Executive Agency (2016b). Annual activity report 2015. Ref. Ares (2016)1983877.

European Commission (2011). 20 years of support for European integration studies. Brussels: European Union.

European Commission (2013). Commission decision delegating powers to the Education, Audiovisual and Culture Executive Agency with a view to performance of tasks linked to the implementation of Union programmes in the field of education, audiovisual and culture comprising, in particular, implementation of appropriations entered in the general budget of the Union and of the EDF allocations. C(2013) 9189 (final).

European Commission (2014). Thinking about Europe. Jean Monnet support to European studies. Brussels: European Union.

Foucault, M. (1978). The history of sexuality. Vol. 1: An introduction. New York: Pantheon Books.

Foucault, M. (2005). The order of things. An archaeology of the human sciences. London/New York: Routledge.

Foucault, M. (1995). Discipline and punish. The birth of the prison. New York: Vintage books.

Guiraudon, V. \& Favell, A. (2007). The sociology of European integration (Paper presented at EUSA, Montreal).

Harrison, J. \& Pukallus, S. (2015). The European Community's public communication policy 1951-1967. Contemporary European History, 24(2), 233-251.

Heilbron, J., Jeanpierre, L. \& Guilhot, N. (2008). Toward a transnational history of the social sciences. Journal of The History of the Behavioral Science, 44(2), 146-160.

Historical Archives of the European Union, EN-2053, Note à l'attention de M. Guy Crauser, Chef de Cabinet par M. Santerelli, Brussels 1 February 1989.

Historical Archives of the European Union, EN-2053, Action Jean Monnet "L'Europe dans I'Université". Réunion de travail du futur Conseil universitaire pour l'Action Jean Monnet, Document de travail pour le point 2 de l'ordre du jour. Brussels, 10 October 1989.

Historical Archives of the European Union, EN-2053. Note sur l'Action Jean Monnet. Enseignements sur l'intégration européenne dans l'université, Brussels 30 June 1989.

Historical Archives of the European Union, EN-2054. Avant-projet Chaire européenne (note de discussion), 14-15 November 1988.

Historical Archives of the European Union, EN-2079. Proposition de décision du Conseil portant adoption du programme d'action de la Communauté Européenne en matière de mobilité des étudiants (ERASMUS), Brussels 7 February 1986. 
Historical Archives of the European Union, EN-2004. Aktion Jean Monnet III. Vade-Mecum III 1992-1993. Brussels, 10 October 1991.

Historical Archives of the European Union, CRE-365, Annex IV. Follow-Up to Action Jean Monnet I (Action Outline).

Hussey, B. (2010). Realism, disciplinary history and European Union studies - From integration theory to normative power Europe. Doctoral thesis, University of Limerick.

Jackson, P. (2011). The Conduct of inquiry in International Relations. Philosophy of science and its implications for the study of world politics. London: Routledge.

Keeler, J. (2005). Mapping EU Studies: The evolution from boutique to boomfield 19602001. Journal of Common Market Studies, 43(3), 551-582.

Klinke, I. (2015). European integration studies and the European Union's eastern gaze. Millennium-Journal of International Studies, 43(2), 567-583.

Kreuder-Sonnen, C. (2016). Beyond integration theory: The (anti-)constitutional dimension of European crisis governance. Journal of Common Market Studies, 54(6), 1350-1366.

Kristensen, P. \& Jensen, M. (2013). The elephant in the room: mapping the latent communication pattern in European Union Studies. Journal of European Public Policy, 20(1), 1-20.

Kurowska, X. \&Kratochwil, P. (2012). The social constructivist sensibility and CSDP research. In X. Kurowska \& F. Breuer (Eds.), Explaining the EU's Common Security and Defence Policy. Theory in Action (86-110), Basingstoke/New York: Palgrave Macmillan.

Lapid, Y. (1989). The third debate: on the prospects of international theory in a post-positivist era. International Studies Quarterly, 33(3), 235-254.

Lastenouse, J. (2011). Entretien avec Jacqueline Lastenouse, directeur honoraire de la Commission européenne, Histoire@Politique, 15(3), 1-21.

Manners, I. (2003). Europaian studies. Journal of Contemporary European Studies, 11(1), 67-83.

Manners, I. \& Whitman, R. (2016). Another theory is possible: dissident voices in theorising Europe. Journal of Common Market Studies, 54(1), 3-18.

McMahon, R. (2017). Progress, democracy, efficiency: normative narratives in political science EU studies. National Identities, 19(2), 231-249.

Mégie, A. \&Vauchez, A. (2014): Crise, crises et crisologie européenne. Politique Européenne, 2(44), 8-23.

Meynaud, J. \& Sidjanski, D. (1965). Science politique et intégration européenne, Institut d'études européennes: Geneva.

Moravcsik, A. (1999a). The future of European integration studies: social science or social theory. Millennium - Journal of International Studies, 28(2), 371-391. 
Moravcsik, A. (1999b). Is something rotten in the state of Denmark? Constructivism and European integration. Journal of European Public Policy, 6(4), 669-681.

Official Journal of the European Communities (2001). Answers given by Mrs Reding on behalf of the Commission. C318/E. 13 November 2001.

Peltonen, M. (2004). From discourse to dispositif: Michel Foucault's two histories. Historical Reflections, 30(2), 205-219.

Pfister, T. (2015). The epistemic dimension of European integration. Innovation, 28(1), 1117.

Pollack, M. (2000). International Relations theory and European integration (EUI Working Paper 55).

Popa, I. (2007). La structuration internationale des études européennes: un espace dissymétrique. In D. Georgakakis \& M. Lassalle (Eds.), La „nouvelle gouvernance européenne" (117-148), Strasbourg: Presses Universitaires de Strasbourg.

Rabier, J.-R. (1965). L'information des Européens et l'intégration européenne. Brussels: Université Libre de Bruxelles.

Risse, T. (2009). Social constructivism and European integration. In A. Wiener \& T. Diez (Eds.), European Integration Theory(159-176). Oxford: Oxford University Press.

Schneider, G., Gabel, M. \& Hix, S. (2001). Editorial statement. European Union Politics, 1(1), 5-7.

Robert, C. \& Vauchez, A. (2010). L'académie européenne: savoirs, experts et savants dans le gouvernement de l'Europe. Politix (89), 9-34.

Rosamond, B. (2007). European integration and the social science of EU studies: the disciplinary politics of a subfield. International Affairs, 83(1), 231-252.

Rosamond, B. (2016). Fields of dreams: the discursive construction of EU studies, intellectual dissidence and the practice of 'normal science'. Journal of Common Market Studies, 54(1), 19-36.

Rosamond, B. \& Manners, I. (2018). A different Europe is possible: the professionalisation of EU studies and the dilemmas of integration in the 21st century. Journal of Common Market Studies, 56(1), 28-38.

Rye, L. (2009). The origins of Community information policy. Educating Europeans. In W. Kaiser, B. Leucht \& M. Rasmussen (Eds.), The History of the European Union: Origins of a Trans- and Supranational Polity 1950-72 (148-166). London: Routledge.

Ryner, M. (2012). Financial crisis, orthodoxy and heterodoxy in the production of knowledge about the EU. Millennium-Journal of International Studies, 40(3), 647-673. 
Schimmelfennig, F. (2012). Constructivist perspectives. In E. Jones, A. Menon \& S. Weatherill (Eds.), The Oxford Handbook of the European Union(34-47). Oxford: Oxford University Press.

Shore, C. (2000). Building Europe: The cultural politics of European integration. London/New York: Routledge.

Smith, A. (2014). Usages scientifiques de "la crise" de 2008 et suite. Le cas des European Studies. Politique Européenne, 2(44), 124-151.

Vauchez, A. \& Mudge, S. (2012). Building Europe on a weak field. Law, economics, and scholarly avatars in transnational politics. American Journal of Sociology, 118(2), 449-492.

Verdun, A. (2003). An American/European divide in European integration studies: bridging the gap with international political economy. Journal of European Public Policy, 10(1), 84101.

Wæver, O. (1998). The sociology of a not so international discipline: American and European developments in International Relations. International Organization, 52(4), 687-727.

Wendt, A. (1992). Anarchy is what states make of it: the social construction of power politics. International Organization, 46(2), 391-425.

Yang, Y. (2015). Does the academic programme work? The Jean Monnet Programme and European Union public diplomacy. Journal of European Integration, 37(6), 611-628. 